\title{
Effect of Support for Entrepreneurship Development on Economic Growth and Development in Nigeria
}

\author{
Saidi Adedeji Adelekan \\ School of Management, Information Technology and Governance, \\ University of KwaZulu-Natal, Durban, South Africa \\ Abideen adekunle Tijani \\ Department of Business Administration, Faculty of Management Sciences, \\ Lagos State University, Ojo, Lagos, Nigeria \\ doi: 10.19044/esj.2017.v13n13p426 URL:http://dx.doi.org/10.19044/esj.2017.v13n13p426

\begin{abstract}
This paper examines the effect of support for entrepreneurship development on economic growth and development in Nigeria with a view to ameliorating some problems militating against the development of Nigeria. Secondary data was sourced from CBN reports, NBS reports and so on. Hypotheses were set and tested by engaging the linear regression method as the analytical tool. The results discovered that government policy has helped in developing entrepreneurs' skill in Nigeria and that whatever polices formulated in the time past has not helped in the development of entrepreneurial skill. In light of these, it was recommended that policies of entrepreneur development and the delivery institutions must be appropriate so that the small industrial units that are being promoted do not fall into a peculiar and complex difficulty.
\end{abstract}

Keywords: Refinancing, Securitization, rediscounting, entrepreneurship, economic growth and development.

\section{Introduction}

Similar to other developing economies, Nigeria has over the past ten years listed and tracked the objective of accelerating the tempo of development for the economy in the bid to change into the assembly of developed or industrialized economies. To achieve these stated development, the effort of the Small and Medium Enterprises (SMEs) cannot be over-emphasized (Onugu, 2005). It is imperative to note that, SMEs are key to the development of most Asian countries, which made them from the third world to the second world (Abe, 2009). The economic boom in some of these Asian countries which is unconnected to SMEs have 
elevated hundreds of millions of people out of poverty and created tens of millions of new middle-class consumers (Tanzer, 2005; Harvie \& Lee, 2002). These SMEs are responsible for driving innovation and competition in many economies, which Nigeria is not an exception. In India, for instance, the SMEs account for about 39\% of manufacturing output and 33\% of total exports (Todd \& Javalgi, 2007; Javalgi \& Todd, 2011). Noteworthy to note is that, SMEs possesses great potential for employment generation, improvement of local technology, output diversification, development of indigenous entrepreneurship and forward integration with large scale industries (CBN, 2011). But in Nigeria, evidence has shown that SMEs have underperformed and have not made significant contribution to the nation's economic growth and development (Onugu, 2005; Genty, 2013; Idris, Adekalu \& Genty, 2014). It is an established fact that developing nations, especially African nations, are faced with the dilemma of choosing appropriate development strategy that could lead to the path of industrialization, which would ensure decent living standards for their teeming population (Onugu, 2005). The pattern of industrial development in most African nations shows that prior to independence, there were little manufacturing activities without sophisticated technology. The predominant economic activities before independence, involved trading in imported finished goods (both consumer and capital goods) and exportation of primary products mainly agricultural and mineral goods, which are locally available in the regions (Gibbon \& Ponte, 2005). Some of these exported products according to Gibbon \& Ponte (2005) includes cocoa, cotton, coffee, groundnut, coal, timber, gold and tin. The post-independence period in Nigeria shows that some efforts were made at local production of industrial goods mainly consumer items (Alagoa, 1970). This policy shows that it resulted in the establishment of turnkey projects which were import dependent in terms of technology, raw materials and skilled labour. These trading activities culminated into the development of SMEs (Chuku, 1999). The big question is if there are supports for SMEs in Nigeria, will they make significant contribution to economic growth and development? That these contributions in term of foreign exchange earners, employment generation, manufacturing output and total export in Nigeria. The emergence and development of entrepreneurship is an important phenomenon in contemporary and developing economies (Stefanovic, Milosevic \& Miletic, 2011). Entrepreneurship is strongly linked to SMEs, which are the main developing force of the developed market economies (Stefanovic, et. al, 2011) that provides the springboard for industrial development and economic growth. Since the economic reform of 1986, there has been a decisive shift of emphasis from the grandiose, capital intensive, large-scale enterprises to SMEs of pre independent. The objective has been to develop 
domestic linkages for rapid sustainable industrial development (Zimmerman \& Chu 2013). Apart from SMEs having the potentials for ensuring a selfreliant industrial development in terms of ability to depend on local raw materials, they also generate more employment per unit of investment and guarantee an even industrial development, including the rural areas (Bullock, et al., 2012). Consequently, governments at all levels in Nigeria are stepping up efforts in promoting the development of SMEs through increased establishment of schemes that render financial and technical assistances to entrepreneurs.

In Nigeria, SMEs provide over $90 \%$ of employment opportunities available in the manufacturing sector and account for about $70 \%$ of aggregate employment created per annum (Onwumere \& Obasi, 2010). SMEs have the potential to serve as engine for wealth creation, employment generation, entrepreneurial skills development and sustainable economic development of Nigeria as the creativity and ingenuity of SMEsentrepreneurs in the utilization of the abundant non oil natural resources of this nation will provide a sustainable platform/spring board for industrial development and economic growth as is the case in the industrialized and economically developed societies (Bhatt, 2014). Van Praag \& Cramer (2001) observed that more jobs are created worldwide through SMEs than large scale enterprises per unit of energy consumed. Also, it is interesting to note that the United States of America, China, Germany, Japan and so on (the large industrialized economy), significantly focus on SMEs as engine of industrial development and economic growth (Ebringa, 2011). These should be the same with all developing countries such as Nigeria. The objective of this paper is to evaluate the effect of support for entrepreneurship development on economic growth and development in Nigeria by reviewing various efforts aim at developing entrepreneurship within the economy and to appraise these efforts on economic growth and development.

The paper is organized in four sections, section I is the introduction, section II deals with conceptual framework and literature review while section III comprises of methodology and section IV is the findings, conclusion and recommendations.

\section{Hypotheses}

1. Government policy has not help in developing entrepreneurs' skill in Nigeria.

2. Promotion of entrepreneurship does not have any correlation to economic growth.

3. There is no significant relationship between entrepreneurship promotion and economic development. 


\section{Conceptual Framework and Literature Review}

In a bid to expand her market access for the SMEs output, Nigeria has signed bilateral, regional and trade preferential agreements with different countries (Okoh, 2006). Apart from signing bilateral agreement with Benin republic, Bulgaria, Equatorial Guinea, Jamaica, Niger, Romania, Turkey, Uganda and Zimbabwe, the government has also signed investment promotion and protection treaties with France, Switzerland, the United Kingdom, the Netherlands, North Korea, China and Turkey (Adepoju, Van Noorloos \& Zoomers, 2010). Nigeria is one of the founding members of Economic Community of West African States and of the World Trade Organization and a signatory of the Lome Convention (Ogunkola \& Oyejide, 2005) despite these efforts non-oil exports have dwindled in the period of great openness (Awolusi, Pelser \& Adelekan, 2016).

\subsection{Concept of Entrepreneur}

One of the commonest terms in daily use in this millennium is the word "entrepreneur" and undoubtedly it remains one of the most difficult to define precisely. Since the word was coined by the French economist J.B. Say about 1800, there has been a total confusion of its definition. Although Say explained that the entrepreneur "shifts economic resources out of an area of lower into an area of higher productivity and greater yield,” he did not say who the “entrepreneur” is. In J B Say's treatise, the entrepreneur "upsets and disorganizes" what Joseph Schumpeter referred to as "creative destruction" by the innovator. While the entrepreneur, in the United States is defined as one who starts his own, new and small business. The English speakers identify entrepreneurship with small business and the Germans identify it 'with power and property. But literature over the years characterizes the entrepreneur as the innovating man, the path-breaker or even the pace-setter of economic and industrial growth. But Drucker defined "entrepreneur" as one who "always searches for change, responds to it and exploits it as an opportunity”. The concept 'entrepreneurship' is popularly associated with private sector economic activities by scholars without given attention has been given to its relevance in the public sector until lately. Hence, there is no single universally accepted definition of entrepreneurship, the definitions varied as there are scholars in the field of entrepreneurship (Byrd \& Hickman, 1992).

Aborisade (2001) posited that in defining the concept of entrepreneurship, there is need to adopt chronological approach in probing the concept. Aborishade traced the concept of entrepreneurship to the eighteenth $\left(18^{\text {th }}\right)$ Century when Richard Cantillon classified economic agents into three categories. Gartner (2007) also define entrepreneurship from the point of view of 'creating value by pulling together a unique 
package of resources to exploit an opportunity'. Similarly, Timmons (1989) perceives entrepreneurship as 'the ability to create and build something from practically nothing. It is initiating, doing, achieving and building an enterprise or organization'. Vesper (1983: 1) views entrepreneurship, not only as a process which creates and implements new ideas but also as a process which introduces new independent competitors to challenge both small and large established companies, seeks niches where there are unsatisfied needs in the marketplace, transfers technology, induces investment and with new methods. Attempting to sum up the various definitions in the literature, Prokopenko (1989) contends that entrepreneurship can be defined in two broad categories: first, as the practice of creating new products or services within existing enterprises, and second, as the practice of creating new, significantly different products, technologies and markets within newly created enterprises. However, Petrin (1991) relates the concept of entrepreneurship to Private Enterprises (PE). To Petrin, entrepreneurship is a process which leads to new combinations of productive factors or otherwise transforms the industrial structure of the public sector. It pertains to the adoption of new forms of business organization, advanced technologies, breaking up of large enterprises, establishment of new enterprises producing goods not previously available.

Ogunkola \& Oyejide (2001) ascertained that, many historical theories of economic development simply postulate the existence of different phases or stages of a development process and hypothesis about the forces that cause a change in the phase or stage of development. The preliminary step in the understanding of any concept is the understanding of what the concept is all about, as well as understanding the theories behind it. Misra and Puri (2005) define economic development as growth plus progressive changes in certain critical variables that determine the wellbeing of the people. But according to Kabir (2014), the problem of development must be defined as a selective attack on the worst forms of poverty. He posits that development goals must be defined in terms of progressive reduction and eventual elimination of malnutrition, disease, illiteracy, squalor, unemployment, and inequalities. Fowowe (2013) noted that one major approach to the concept of economic development, referred to as the traditional approach. Hence, he defines traditional approach as the development strictly in economic terms, that it implies a sustained annual increase in Gross National Product (GNP) at rates varying from 5 to 7 percent or more, together with such alteration in the structure of production and employment that decreases the shares of agriculture in production and employment and increases those of manufacturing and services sectors.

It is worth noting the difference between economic development and economic growth, as these two important economic concepts have often 
been misplaced and confused in their meanings (Adelekan \& Dansu, 2016). Distinguishing between economic growth and development, recent literature such as Adelekan (2016) notes that economic growth refers to increases in a country's real output of goods and services or product per capita over time. Output is generally measured, in this case, by gross or net national product, the term economic development, on the other hand, is more comprehensive. It implies progressive changes in the socio-economic structure of a country.

\subsection{Entrepreneurship Development in Nigeria}

Development is defined as gradual advancement through progressive stages of growth from within (Shariff \& Saud, 2009). Hathaway (2013) considered development as a systematic process of training and growth through which the individuals gain and apply skill, knowledge, insight and attitude to manage work organization effectively. Development is thus seen as a process which involves growth. These features of development imply "change". The developmental approach to entrepreneurship, considers nurturing the actual or potential entrepreneurs to become effective in running their own organizations. This has to be done at various stages and in various institutions, (Singh, Verma \& Anjum, 2006), he observed that entrepreneurial performance is influenced by three factors.

* His own attitude towards his occupation.

* Role expectations held by the sanctioning groups.

* Operational requirements of the job.

He noted that society's values are the most important determinants of the first two factors. Ekpo-Ufot (1990) gave an account of an entrepreneurship development programme that was carried out at the University of Lagos. He therefore, produced a list of seven determinants that affect entrepreneurship responses. These determinants are;

$0 \quad$ society's values and needs

o family,

o schools

o work organization,

o urbanization and industrial estates

o availability of financial resources and government.

He posited that structured and restructured helps to accelerate entrepreneurship development. Researches had engineered governmental responses in seeking to address reported and observed obstacles facing indigenous entrepreneurs in Nigeria. Like every other governmental policies, laudable with poor implementation which is the same thing with all government policies in Nigeria. Government established and funded several research institutions that have succeeded in developing myriads of simple technologies, technical tools and innovations but they are not significantly 
applied by the small-scale enterprises: The Federal government established Industrial Development Centres (IDCs) one each in every state of the Federation. There are four zonal centres in Owerri, Oshogbo, Zaria and Bauchi. These four centres have workshops that provide services for would be and actual entrepreneurs in metal and wood works, leather, textile, automobile, ceramics and electrical/electronic areas. The IDCs system was introduced to provide grassroots support to the development of small and medium scale entrepreneurs (Aremu \& Adeyemi, 2011). Government has also put in place financial institutions to aid those enterprises like Peoples Bank (of old), National Economic Reconstruction Fund (NERFUND) and Central Bank of Nigeria made deductions from gross profits of banks to be invested in SMEs as equity shares holdings. The National Directorate of Employment (NDE) and National Poverty Eradication Programme (NAPEP) are put in place to provide training and financial assistance to SMEs entrepreneurs. It is important to note that each of the states of the Federation also have their own entrepreneurial development programmes that are complementary to the Federal Government Efforts. There is also the small and medium enterprises development agency (SMEDA), The National Economy Empowerment and Development Strategy (NEEDS) with its state and local government system fashion State Economy Empowerment and Development Strategy (SEEDS) and local economic empowerment and development strategy (LEEDS) put in place by the present administration of their focus in developing indigenous entrepreneurs (Marcellus, 2009). Tertiary educational institutions, especially the Polytechnics and Universities have fashioned out small business management and entrepreneurship development course to equip existing and would be entrepreneurs with necessary technical and managerial skills (Garba, 2010). Also, international organizations and associations had given support in forms of fund and training programmes for entrepreneurs e.g. The Commonwealth and Ford Foundation. Where then is the missing link?

\subsection{Various Intervention and Support Programme}

\section{The Nigerian Entrepreneur Development Programme (EDP) Model}

The Entrepreneur Development Programme (EDP) initiative started in Nigeria with the involvement of the Federal Government; the Centre for Management Development (CMD); the Nigeria Bank for Commerce and Industry (NBCI); the Administrative Staff College of Nigeria (ASCON); the National Youth Service Corps (NYSC) and the higher institutions. The Federal Ministry of Employment, Labour and Productivity were made responsible for collating various EDP proposals and forwarding them to the National Directorate of Employment (NDE) for processing. The CMD which was the Coordinator of the EDP for the Federal Government was to 
organize entrepreneurial programmes in all the states of the federation and ASCON was to develop programmes in small business management (Garba, 2010; Marcellus, 2009).

The higher institutions (universities/polytechnics) were to evolve a curriculum for a short course on entrepreneurial training for their final year students. The proposed duration of the course was two weeks and it was to be run in the middle of the year after the first semester examinations. The National Youth Service Corps Secretariat was to set up entrepreneurship training programme either during the orientation period or at the end of the service year.

\section{Techno-Serve Programme (Nigeria)}

The major objective of Techno Serve programme is to improve the economic and social well-being of low income people in developing countries through a process of enterprise development which increases jobs, productivity, and income. This is accomplished by providing management, technical assistance and training to enterprises and institutions primarily related to the agricultural sector. It does not provide money and equipment.

The programme seeks to support local institutions which can undertake work similar to those of Techno-Serve but which reach a much larger audience (Othman, Bolorunduro, Ibrahim \& Dayot 2009; Janvier, Baco, Ismaïl, Akponikpe, Yegbemey \& Tossou, 2014). An example of this in Nigeria is the assistance given to Farmers Development Unions in Nigeria. All needs assessment and training are participatory and Techno Serve generally includes group members in the planning and implementation of all activities including:

Feasibility studies
Marketing analysis
Booking techniques
Processing techniques
Choice of technology
Projects monitoring and

Assistance is considered for enterprise groups with the following characteristics:

- $\quad$ Evidence of strong financial and social commitment of entrepreneur

$\bullet$

of the rural poor
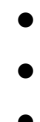

Potential to improve the social and economic well being

Respond to the needs of the local community

Broad base of-ownership by the poor

Appropriate local leadership 
Ecologically appropriate to the local environment and

Do not discriminate in favour of a particular group or sex.

Potential beneficiaries must be prepared to invest their own funds (in the enterprise) no matter how little. So far, Techno Serve is providing Technical services to about 16 community based agricultural related projects in Nigeria.

Techno Serve is currently providing assistance to facilitate the establishment and provision of institutional support to a newly established local financial intermediary (called the Nigerian Community Development Trust Fund, NCDTF), with the objective of integrating formal and informal credit systems through the provision of organizational planning grants to enable it serve Community Development Associations as well as provide loan guarantees to small and medium scale rural businesses (Othman et al., 2009).

\section{Empretec Programme}

The objective of the programme is to act as a catalyst for private sector, participation in national development by helping and supporting small and medium scale entrepreneurs operating in that sector and thereby encouraging private enterprise and job creation (Mugione, 2013; Adelekan, 2016). This programme operates in Nigeria, Ghana and other African countries (Mugione, 2013). Contributions of entrepreneurs to the development of all nations have been recognized over the years. Often, entrepreneurs start in a modest way and have as the main objective the creation of new products or processes, the finding of new materials and markets and the designing of new and more effective forms of organization within the usually limited resources. Many developing countries have tried to develop entrepreneurial talents, but with little results. It is important to make the point that studies such as Sanyang \& Huang, 2010; Urbano \& Aparicio, 2016) conducted in various countries to identify why entrepreneurs fail and why entrepreneurial talents are lacking have established that potential entrepreneurs can be identified, trained and financed and made to succeed; and that in reality, entrepreneurs' problems arise more out of the lack of ability to identify them than from the nonexistence of potential successful entrepreneurs (Ekpeyong, 1988).

\subsection{Direct Incentive to Manufacturers}

Nigeria's macroeconomic policies over the years have been adopted with a view to achieve growth in non-oil exports particularly manufactures. For instance, in the 1960s and 1970s manufactured merchandize exports grew under high protective fiscal barriers. In the 1980s however with the fall in crude oil exports the major earners of foreign 
exchange in Nigeria manufacturers were unable to import capital inputs. The results were a decline in the growth of output and hence manufactured exports. Macroeconomic policy thus had to refocus its objective towards restructuring productive activities under the framework of Structural Adjustment Programme (SAP) in mid-1986 which was introduced to revitalize the manufacturing sector through removal of over valuation of exchange rate and subsequent determination by the market forces, tariff reforms; removal of price controls to enable producers operate competitively (Titiloye \& Victor, 2014). Other objectives included diversifying the economy away from its heavy reliance on oil revenues and improving the economy's future growth as well as public sector reforms through privatization, commercialization programmes and fiscal prudence.

Macroeconomic policy efforts included the embarkation of the Nigerian government on a number of incentive schemes with a view to encouraging exporters of non-oil merchandize to produce more, as well as to enhance their capacity to produce and export. The Nigerian Export Promotion Council (NEPC) was established in 1976 charged with the responsibility to administer the export incentives, which were designed to encourage a meaningful diversification of the economy. The council operates a number of funds, that is, the Export Development Fund (EDF), The Export Expansion Grant Fund (EEGF) And the Duty Draw Back Scheme (DDBS). The export expansion grant was aimed at identifying and encouraging producers to produce for export rather than for the domestic market. The council was saddled with the responsibility of generating information through export market surveys and other methods of information gathering in other to collect information on trade restriction, import requirements and characteristics of various markets, as well as conduct studies to identify goods that would be readily acceptable to the European Union, the Commonwealth and the Economic Community of West African State (ECOWAS). The council was to establish commercial desks and centres overseas. These desks and centres were meant to collect, collate and disseminate useful information to Nigerian exporters, link Nigerian exporters with potential importers, assist Nigerian trade missions and individual businessmen on trips and facilitate Nigeria's participation in international trade fairs and exhibitions.

The Nigerian Export Bank (NEXIM) was established in 1988 to promote non-oil exports further. It was to provide a range of financial facilities, including short-term supplier of credit and external trade facilities. The two currently functional schemes of NEXIM are Rediscounting and Refinancing Facilities (RRF) and the Stocking Facility (SF). These incentives are expected to enhance the capacity of banks and to encourage them to expand their export financing business. The refinancing and 
rediscounting facilities were aimed at providing liquidity to banks in a bid to enhance their capacity to support export promotion and development.

Other incentives included the currency retention scheme, which was aimed at allowing exporters to keep their proceeds in foreign currency. This was expected to ease access to foreign currency when it is needed for importation of capital inputs and other goods. Tax relief on exports and export credit guarantee and insurance schemes were aimed at reducing banks tax burden and risk in export financing. The export price adjustments and subsidy scheme for use of local raw materials in export production were aimed at compensating exporters whose foreign prices fall below costs as well as to encourage local sourcing of raw materials. Nigeria however has no commitments on export subsidies. The abolition of export licensing and export liberalization measures was aimed at removing administrative bottlenecks and hence promotes export trade.

The supplementary allowances for pioneer companies and accelerated depreciation incentive measures were aimed at encouraging pioneer companies and industrialists to expand their exports. The exportprocessing zone was created to stimulate export. Despite these incentives the non-oil export has not shown an encouraging performance.

Table 1: Incentive Schemes Adopted to Boost Non-oil Exports in Nigeria.

\begin{tabular}{|c|c|c|c|c|}
\hline SN & $\begin{array}{l}\text { Starting } \\
\text { Date }\end{array}$ & $\begin{array}{l}\text { Incentive } \\
\text { scheme }\end{array}$ & Operation agent & Objective and remark \\
\hline 1 & 1970 & $\begin{array}{l}\text { Abolition of } \\
\text { export licensing }\end{array}$ & $\begin{array}{l}\text { Federal Ministry of } \\
\text { Commerce and Tourism }\end{array}$ & $\begin{array}{l}\text { To remove administrative } \\
\text { obstacles from the export sector } \\
\text { as much as possible. }\end{array}$ \\
\hline 2 & 1970 & $\begin{array}{l}\text { Supplementary } \\
\text { allowance in } \\
\text { favour of pioneer } \\
\text { companies. }\end{array}$ & $\begin{array}{l}\text { Federal Ministry of } \\
\text { Commerce and Tourism }\end{array}$ & $\begin{array}{l}\text { To extend supplementary } \\
\text { incentives to pioneer companies } \\
\text { that exports their products. }\end{array}$ \\
\hline 3 & 1977 & $\begin{array}{l}\text { Export expansion } \\
\text { grant }\end{array}$ & NEPC & $\begin{array}{l}\text { To encourage companies to } \\
\text { engage in export business rather } \\
\text { than domestic business: } \\
\text { especially exporters who have } \\
\text { exported N50, 000 worth of } \\
\text { semi-manufactured } \\
\text { manufactured products. }\end{array}$ \\
\hline 4 & 1977 & $\begin{array}{l}\text { Export } \\
\text { adjustment }\end{array}$ & NEPC & $\begin{array}{l}\text { This is a form of export subsidy } \\
\text { designed to compensate } \\
\text { exporters of products whose } \\
\text { foreign prices become relatively } \\
\text { unattractive, due to factors } \\
\text { beyond their control. }\end{array}$ \\
\hline 5 & 1986 & $\begin{array}{l}\text { Current retention } \\
\text { scheme }\end{array}$ & $\begin{array}{l}\mathrm{CBN} \text { and } \text { the } \\
\text { commercial } \backslash \text { merchant } \\
\text { Banks. }\end{array}$ & $\begin{array}{l}\text { To enable exporters to hold } \\
\text { export proceeds in foreign } \\
\text { currency in their banks. }\end{array}$ \\
\hline 6 & 1990 & Tax relief on & Banks and Federal Board & To encourage banks to finance \\
\hline
\end{tabular}




\begin{tabular}{|c|c|c|c|c|}
\hline & & $\begin{array}{l}\text { export earned by } \\
\text { banks on export } \\
\text { credit. }\end{array}$ & of Inland Revenue & $\begin{array}{l}\text { export by reducing their tax } \\
\text { burden }\end{array}$ \\
\hline 7 & 1991 & $\begin{array}{l}\text { Export } \\
\text { processing zone }\end{array}$ & $\begin{array}{l}\text { Federal Ministry of } \\
\text { Commerce and Tourism. }\end{array}$ & $\begin{array}{l}\text { Opened in mid-1996 in Calabar, } \\
\text { to facilitate and enhance exports. }\end{array}$ \\
\hline 8 & 1991 & $\begin{array}{l}\text { Accelerated } \\
\text { depreciation and } \\
\text { capital } \\
\text { allowance. }\end{array}$ & $\begin{array}{l}\text { Federal Ministry of } \\
\text { Commerce and Tourism. }\end{array}$ & $\begin{array}{l}\text { To extend supplementary } \\
\text { incentives to industrial } \\
\text { organization for export of their } \\
\text { products. }\end{array}$ \\
\hline 9 & 1992 & $\begin{array}{l}\text { Subsidy scheme } \\
\text { for use of local } \\
\text { raw materials in } \\
\text { export } \\
\text { production. }\end{array}$ & NEPC & $\begin{array}{l}\text { To encourage exporters to use } \\
\text { local raw materials in export } \\
\text { production. }\end{array}$ \\
\hline 10 & 1997 & $\begin{array}{l}\text { Export } \\
\text { development } \\
\text { fund }\end{array}$ & NEPC & $\begin{array}{l}\text { To assist exporters in partly } \\
\text { paying the costs of participation } \\
\text { in trade fairs, foreign market } \\
\text { research etc. }\end{array}$ \\
\hline 11 & 2002 & $\begin{array}{l}\text { Refinancing and } \\
\text { rediscounting } \\
\text { facility(RRF) } \\
\text { And foreign } \\
\text { input facility }\end{array}$ & $\begin{array}{l}\text { Central Bank of } \\
\text { Nigeria.(CBN\NEXIM) }\end{array}$ & $\begin{array}{l}\text { To provide liquidity to banks in } \\
\text { support of their export finance } \\
\text { business directed at export } \\
\text { promotions and development. }\end{array}$ \\
\hline 12 & 2009 & $\begin{array}{lr}\text { Export } & \text { credit } \\
\text { guarantee } & \text { and } \\
\text { insurance } & \\
\text { scheme. } & \end{array}$ & CBN\NEXIM & $\begin{array}{l}\text { Assists banks to bear the risks in } \\
\text { export business and, thereby, } \\
\text { facilitates export financing and } \\
\text { export volumes. }\end{array}$ \\
\hline 13 & 2009 & $\begin{array}{l}\text { Duty drawback } \\
\text { scheme }\end{array}$ & $\begin{array}{l}\text { Customs Department; } \\
\text { Standard Organization of } \\
\text { Nigeria, Nigeria Export } \\
\text { Promotion Council, } \\
\text { (NEPC) Commercial and } \\
\text { Merchant Banks and } \\
\text { CBN. }\end{array}$ & $\begin{array}{l}\text { To reimburse customs duty paid } \\
\text { by exporters on imported input } \\
\text { used for export production. This } \\
\text { has not been widely used by } \\
\text { exporters due to the } \\
\text { cumbersome procedural } \\
\text { requirements involved, although } \\
\text { the fund has been increased to } \\
\$ 50 \text { milion (Us per cent } \\
43.5 \text { milion). }\end{array}$ \\
\hline 14 & 2009 & $\begin{array}{l}\text { Manufacturing } \\
\text { bond scheme. }\end{array}$ & $\begin{array}{l}\text { Federal Ministry of } \\
\text { Commerce and Tourism. }\end{array}$ & $\begin{array}{l}\text { To assist potential exporters of } \\
\text { manufactured product to import } \\
\text { raw materials duty-free for } \\
\text { production of exportable } \\
\text { products. }\end{array}$ \\
\hline 15 & 2009 & $\begin{array}{l}\text { Export } \\
\text { liberalization } \\
\text { measures } \\
\text { buyback } \\
\text { arrangement. }\end{array}$ & $\begin{array}{l}\text { Federal Ministry of } \\
\text { Commerce and Tourism. }\end{array}$ & $\begin{array}{l}\text { To liberalize, and promote } \\
\text { export trade. }\end{array}$ \\
\hline
\end{tabular}

Sources: (1) CBN, (1960 -2015) Annual Reports. 


\section{$2.5 \quad$ Trade Support Agents}

Nigeria's performance in international trade is a sad story of significant under-achievement. Hence government encourages and established Trade Support Institutions (Rose, 2007).

Nigerian Export Promotion Council (NEPC): This is the central agency created by the Federal Government of Nigeria to promote the development of non-oil exports in the country. The council has statutory responsibilities for advising the Government on new and viable export developmental policies, evolving new incentives to spur increased export activity. Its task is to spearhead the participation of Nigerian companies in overseas international trade fairs, organize solo exhibitions of made-inNigerian products in selected overseas markets; provide an efficient trade information network that would effectively link Nigerian exporters with overseas markets, and carry out periodic supply-base studies of Nigeria's export commodities and potential and so on (Rose, 2007: Adenikinju \& Chete, 2002). Under the decree establishing a new autonomy and dynamic orientation for the Nigerian Export Promotion Council, 18 distinct statutory responsibilities were actually assigned to the agency.

Presently, more than forty (40) years after, the council's impact is hardly felt by up the nation's non-oil export industry. More importantly, up to five of the "established" export incentives are not working. Various reasons can be found for this.

Nigerian Export Processing Zones Authority: The Nigerian Export Processing Zones Authority was created a few years after the new Nigerian Export Promotion Council took off. NEPZA was, in fact, one of the brilliant suggestions of the NEPC as an innovative global strategy to simplify and reduce the cost of export manufacture. Government spent enormous sums in carrying out a preliminary study of Export Processing Zones in Malaysia, Taiwan and Kenya. Over the past ten years or so, Government has attempted to build an Export Processing Zone in Calabar, a South Eastern sea port. More than eight Ministers of Commerce and fabulous budgetary expenditures later, the zone is yet to be commissioned. As an institution, it is left to be seen how it will support trade from Nigeria, even though it has received a new nomenclature of Free Trade Zone.

Nigerian Investment Promotion Commission: Like NEPC, the Nigerian Investment Promotion Commission was set up to attract Foreign Direct Investment into Nigeria. Ordinarily, investment promotion should be inward, but when it is considered that the output of all meaningful investment, especially in the manufacturing sector, is export-oriented, the activities of the commission will indirectly impact on international trade. Unfortunately, the two organizations whose activities are supposed to 
complement each other see each other as rivals for the very stingily distributed Government subventions (Adenikinju \& Chete, 2002).

Nigerian Export-Import Bank: The bank was set up, ostensibly to provide easy access to export financing for potential manufacturing exporters and export merchants in Nigeria. Over the past few years, however, the bank has had to go looking for funds from elsewhere even to keep afloat. The maximum allocated to the bank, over the past five years has been about eight hundred million Naira per annum, hardly adequate even as working capital support for a cocoa processing plant, of which Nigeria has more than seventeen.

Industrial Development Co-ordinating Committee: The committee was established by decree No.36 of 30th September, 1988, to administer business industry approvals. The general objective was to facilitate the approval process for investment in the country's technological development and therefore improve international trade, by serving as a coordinating and approving centre, at the federal level, for all government approvals with respect to the establishment of new industries and business undertakings, and with respect to the operation of governmental schemes and policies aimed at promoting industrialization in the country. In order to facilitate its operation and make it a veritable “one-stop approval centre”, its membership was made up of seven Ministers of related portfolios who were collectively charged with the responsibility for ensuring that all required approvals are granted within 60 days. Again, these responsibilities would seem to have been carried out only on paper. The non-performance of the committee, it is believed, might have led to the emergence of the Nigerian Investment Promotion Commission, which is headed by an Executive Chairman from the Private Sector (Oduleru, 2009).

State Committees on Export Promotion: The Nigerian Export Promotion Council led to the creation of an export promotion committee for every State of the Federation including Abuja. It is however doubtful whether many of these have achieved any visible milestone achievements.

Association of Nigerian Exporters: A non-governmental organization that is supposed to provide trade information and advisory services to its members, the Association of Nigerian Exporters had been moribund for the past ten years or so until its resuscitation in the last twelve months.

Manufacturers Association of Nigeria-Export Group: Conceived as a pressure group to fight for a better and more conducive environment for export manufacturing, the Group was once strong enough to provide inputs for Government's policies on Export. Today, due to continual leadership tussles, it has lost its bite, and membership has waned. 
Nigerian Association of Chambers of Commerce, Industries, Mines and Agriculture - Export Group: Also supposed to provide export advisory services for its members, membership is however very defective and needs export education.

Lagos Chamber of Commerce, Industries Mines and Agriculture, Non-oil Export Group: Conceived for the same services as above.

Department of Commodities and Export Trade, Federal Ministry of Commerce: Appears to have the same responsibilities as the Nigerian Export Promotion Council, except that the department is under the Ministry and therefore enjoys closer supervision and a preferential relationship with the Minister of Commerce, who is also the supervising Minister for the Export Promotion Council as well as the Nigerian Export Processing Zones Authority.

Some other bodies in the network:

* Export Commodities Co-ordinating Committee

* Nigerian Shippers Council

* Nigerian Institute of Freight Forwarders

* Nigerian Maritime Authority

* Nigerian Ports Authority

* Nigerian Customs Service

* National Association of Small Scale Industrialists

Various bilateral Chambers; e.g. Nigerian-British Chamber of Commerce, * Nigerian-French,

* Nigerian American, Nigerian-Portuguese, etc. Chambers of Commerce

* Bankers Committee

* Federal Ministry of Finance

* Senate Committee on Commerce

* House of Representatives Committee on Commerce

\section{Methodology}

This study adopts the descriptive research method which described the nature of relationship between variables under investigation (Cooper, Schindler \& Sun, 2003). Analytical framework adopted is the linear regression analysis of Ordinary least square (OLS). It was selected because of its explanatory ability, theoretical plausibility and accuracy of estimates of parameters, among others and its ability to establish the cause and effect between variables. The statistical analysis was done with SPSS 23.0 version. 


\subsection{Model Specification}

The model specification is presented in form of $\mathrm{Y}$ depending on $\mathrm{X}$ and put in mathematical form;

$$
\mathrm{Y}=\beta_{0}+\beta_{1} \mathrm{X}+\mu
$$

In hypothesis I; government policy is represented by amount of fund disbursed to SMEs and contribution of SMEs to Gross Domestic Product (GDP) is used to represent entrepreneurial skill.

Where;

$Y=$ Contribution of SMEs to Gross Domestic Product (the Dependent variable)

$\mathrm{X}=$ Amount disbursed to SME ${ }^{\prime}$ million $\beta_{0}=$ Constant Term

$\beta_{1}=$ coefficient of the parameters $X_{1}$

$\mu=$ Stochastic Error Terms

And in hypothesis II, promotion of entrepreneurship is represented by Amount disbursed to SME million and economic growth is represented by Gross Domestic product (GDP).

Where;

$\mathrm{Y}=$ Economic Growth (the Dependent variable)

$\mathrm{X}_{1}=$ Amount disbursed to SME Nm

Hypothesis III, entrepreneurship promotion and economic development which is represented by inflation rate, unemployment rate and exchange rate, in other to avoid spurious data problem amount disbursed to SMEs is reduced to the rate of change in the variable over time under study.

Then;

$Y=$ Rate of change in Amount disbursed to SME Nm (the Dependent variable)

$\mathrm{X}_{1}=$ Inflation rate

$\mathrm{X}_{2}=$ Unemployment rate

$\mathrm{X}_{3}=$ Exchange rate

\subsection{Interpretation of Results}

In hypothesis I, the linear regression line $Y=\beta_{0}+\beta_{1} X+\mu$ with its respective standard errors could now be written as:

$\mathrm{Y}=877336.529+138.646 \mathrm{X}+1206864.05341$

The regression line shows that there is a positive regression between Contribution of SMEs to Gross Domestic Product and Amount disbursed to SMEs, with the level of co-efficient of correlation (R) is 0.628 and the value of coefficient of correlation or 'the goodness of fit' $\left(\mathrm{R}^{2}\right)$ is equal to 0.595 which mean that 59.5 percent changes observed in Contribution of SMEs to Gross Domestic Product can be ascribe to the amount disbursed to SMEs. 
Therefore, reject the null hypothesis that Government policy has not help in developing entrepreneurs' skill in Nigeria.

In hypothesis II, the linear regression line $Y=\beta_{0}+\beta_{1} X+\mu$ with its respective standard errors could now be written as:

$\mathrm{Y}=409217.632+24.871 \mathrm{X}+138584.12109$

The regression line shows that there is a positive regression between Gross Domestic Product and amount disbursed to SMEs, with the level of co-efficient of correlation $(\mathrm{R})$ is 0.784 and the value of coefficient of correlation or 'the goodness of fit' $\left(\mathrm{R}^{2}\right)$ is equal to 0.614 which mean that 61.4 percent changes observed in Gross Domestic Product can be ascribe to the amount disbursed to SMEs. Therefore, reject the null hypothesis that promotion of entrepreneurship does not have any correlation to economic growth.

In hypothesis III, the linear regression line $Y=\beta_{0}+\beta_{1} X+\mu$ with its respective standard errors could now be written as:

$$
\mathrm{Y}=-10273688.396-63443.405 \mathrm{X}_{1}+95845.291 \mathrm{X}_{2}+90522.504 \mathrm{X}_{3}+
$$
848419.99857

The regression line shows that there is a negative regression plane between rate of change in Amount disbursed to SME, Inflation rate, Unemployment rate and Exchange rate, with the level of co-efficient of correlation $(\mathrm{R})$ is 0.881 and the value of coefficient of correlation or the goodness of fit' $\left(\mathrm{R}^{2}\right)$ is equal to 0.776 which mean that 77.6 percent changes observed in Rate of change in Amount disbursed to SME is due to combine influence of Inflation rate, Unemployment rate and Exchange rate. Therefore, reject the null hypothesis that there is no significant relationship between entrepreneurship promotion and economic development.

\section{Summary of Findings}

It was discovered that from the analysis that government policy has help in developing entrepreneurs' skill in Nigeria and that whatever polices formulated in the time past has not helped in development of entrepreneurial skill. To compound is the business environment in country that has not support new investment despite the fact that it was generally agree that entrepreneur promotion is a necessary strategy for economic development. It was also discovered that promotion of entrepreneurship is directly related to economic growth. It was established that lack of entrepreneurship development strategy leads to shortage of essential goods and services which resulted into increase inflation rate. Majority of the respondents agree that promotion of entrepreneurship in Nigeria will improve living standard of citizen and entrepreneurship process mismanagement has not help capacity utilization in manufacturing sector. 


\section{Conclusion}

It has been established that, an entrepreneur is person who assumes the responsibility and the risk for a business operation with the expectation of making a profit. The entrepreneur generally decides on the product, acquires the facilities, and brings together the labour force, capital, and production materials. If the business succeeds, the entrepreneur reaps the reward of profits; if it fails, he or she takes the loss. The success of all promotional measures in uplifting entrepreneurial performance and small scale industries in developing economies depends mainly on the entrepreneur; his skill, responses, attitudes, skills and ability to absorb the support provided. Hence, promoters of business idea must also possess entrepreneurial skills to be able to fulfill the roles specified. They have to practice in their managements:

* Systematic innovation;

* Change-orientation;

* Opportunity-focus; and

* Empowering leadership.

Once in a while they must perform self appraisal of their institutions, and be honest in critiquing their management practices; they must see their staff as assets rather than threats or liabilities. These are the challenges that confront our management development institutes.

\section{Recommendations}

Hardly can one find a country today which does not include the development of the small industrial sector as a focus for economic development. In some countries, it forms a significant part of the conditionality attached to World Bank IMF facilities through the Structural Adjustment Programme. The following recommendations were made;

* Policies of entrepreneur development and the delivery institutions must he appropriate so that the small industrial units that are being promoted do not fall into a peculiar and complex difficulties. The level of industrial development should be reflected in the type and kind of Small Scale Enterprises (SMEs) policies which are being promoted.

* Policy objectives should be stated and stipulated very concisely and the policies should reach all levels and categories of entrepreneurs in urban ax rural areas.

* Small Scale Industry (SSI) should be declared a priority sector within the national policy framework supported with effective and practical policies at all levels.

* All legal and administrative constraints inhibiting the promotion and development of the small industrial sector should be removed. 
* Government should initiate an integrated and well coordinated SSI development and entrepreneurship programme. This pre-supposes that factors such as training, finance, market, raw materials, extension services, etc., must be available to small scale industries from specific institutional support systems.

* Governments should promote, encourage and facilitate the Non Government Organizations (NGOs) so that they could play an effective role in the field, NGO activities and programmes should, where possible, be directed and coordinated and should fall within the national policy objectives and framework.

* With the growing importance of training and the increased need for its coordination, every country may wish to set up a "National Resource Institute exclusively devoted to entrepreneurship training and development.

* A national women entrepreneurship training program that would build self- actualization, confidence and independence in women should be designed.

* Entrepreneurship development follows a cycle consisting of stimulating, support and sustaining activities. Each group of activities is highly interacting, supplementary and crucial to one another. The support and sustaining activities should be considered as the integral part of the total package of entrepreneurship and small industry development.

\section{References:}

1. Abe, M. (2009). Globalization of Production and the Competitiveness of SMEs in Asia and the Pacific: Trends and Prospects. Studies in Trade and Investment, 65, 33-57.

2. Aborisade, A. (2001). The wonder of mathematics.

3. Adelekan, S.A. (2016). The impact of organisational culture on innovation capability of SMES case study of SMES in Alimosho and Ojo Local Government Area of Lagos State, Nigeria. International Journal of Economics, Commerce \& Management, 6(9), 158-181.

4. Adelekan, S.A. \& Dansu, O.O. (2016). Impact of entrepreneurship ventures on development of small and medium enterprises in Nigeria case study of three territorial district in Osun state, Nigeria. International Journal of Economics, Commerce \& Management, 6(9), 423-441.

5. Adenikinju, A. F., \& Chete, L. N. (2002). Productivity, market structure and trade liberalization in Nigeria (Vol. 126). Nairobi: African Economic Research Consortium.

6. Adepoju, A., Van Noorloos, F., \& Zoomers, A. (2010). Europe’s Migration Agreements with Migrant-Sending Countries in the 
Global South: A Critical Review. International migration, 48(3), 4275.

7. Alagoa, E. J. (1970). Long-distance trade and states in the Niger Delta. The Journal of African History, 11(03), 319-329.

8. Aremu, M. A., \& Adeyemi, S. L. (2011). Small and medium scale enterprises as a survival strategy for employment generation in Nigeria. Journal of sustainable development, 4(1), 200.

9. Awolusi, O. D., Pelser, T. G., \& Adelekan, S. A. (2016). Determinants of Foreign Direct Investment: New Granger Causality Evidence from Asian and African Economies. Journal of Economics and Behavioral Studies, 8(1), 104-119.

10. Bhatt, N. J. (2014). Productivity in small and medium enterprises of India: A Cobb-Douglas production function approach. IUP Journal of Management Research, 13(1), 29.

11. Bullock, J., Chapman, D., Schaffer, S., Roy, D., Girardello, M., Haynes, T., \& Tinch, R. (2012). Assessing and controlling the spread and the effects of common ragweed in Europe (ENV. B2/ETU/2010/0037). European Commission, Final Report.

12. Byrd, J. W., \& Hickman, K. A. (1992). Do outside directors monitor managers?: Evidence from tender offer bids. Journal of financial economics, 32(2), 195-221.

13. CBN, (1960 -2015) Annual Reports.

14. Chuku, G. I. (1999). From Petty Traders to International Merchants: A Historical Account of Three IGBO Women of Nigeria in Trade and Commerce, 1886 to 1970. African economic history, (27), 1-22.

15. Cooper, D. R., Schindler, P. S., \& Sun, J. (2003). Business research methods.

16. Ebiringa, O. T. (2011). Entrepreneurship Venturing and Nigeria's Economic Development: The Manufacturing Sector in Focus. International. Journal of Business Management \& Economic Research, 2(6), 376-381.

17. Ekpenyong, L. E. (1988). Vocational content in the national curriculum for Nigerian Secondary Schools: How industry can help. The Vocational Aspect of Education, 40(106), 57-62.

18. Ekpo-Ufot, A. (1990). Exploratory Research on acts of indiscipline in Lagos State. Unpublished research report.

19. Fowowe, B. (2013). Financial Liberalization in Sub-Saharan Africa: What Do We Know?. Journal of Economic Surveys, 27(1), 1-37.

20. Garba, A. S. (2010). Refocusing education system towards entrepreneurship development in Nigeria: a tool for poverty eradication. European Journal of social sciences, 15(1), 140-150. 
21. Gartner, W. B. (2007). Is there an elephant in entrepreneurship? Blind assumptions in theory development. In Entrepreneurship (pp. 229-242). Springer Berlin Heidelberg.

22. Genty, K. I. (2013). Perception of Microcredit Schemes on Growth and Development in Informal Sector of Nigeria Economy: A Study of Selected Small-Medium Scale Enterprises (SMEs) in Lagos State, Nigeria.

23. Gibbon, P., \& Ponte, S. (2005). Trading down: Africa, value chains, and the global economy. Temple University Press.

24. Harvie, C., \& Lee, B. C. (Eds.). (2002). Globalisation and SMEs in east Asia (Vol. 1). Edward Elgar Publishing.

25. Hathaway, I. (2013). Tech starts: High-technology business formation and job creation in the United States. Ewing Marion Kauffman Foundation Research Paper.

26. Idris, K., Adekalu, S. O., \& Genty, K. I. (2014). Organisation Development and Strategic Intervention for Enterprise Sustainability: Empirical Evidence from Nigeria. British Journal of Arts and Social Science, 16(2), 156-171.

27. Janvier, E. G. A. H., BACO, M. N., Ismaïl, M., AKPONIKPE, P. B. I., YEGBEMEY, R. N., \& TOSSOU, R. C. (2014). Performance of Institutional Innovation: The Case of Maize-Related Warrantage in Benin, West Africa.

28. Javalgi, R. R. G., \& Todd, P. R. (2011). Entrepreneurial orientation, management commitment, and human capital: The internationalization of SMEs in India. Journal of Business Research, 64(9), 1004-1010.

29. Kabir, M. (2014, January). Entrepreneurship Through the Lens of Persons with Disabilities. In ICSB World Conference Proceedings (p. 1). International Council for Small business (ICSB).

30. Marcellus, I. O. (2009). Development planning in nigeria: reflections on the national economic empowerment and development strategy (NEEDS) 2003-2007. Journal of social sciences, 20(3), 197-210.

31. Misra, S. K., \& Puri, V. K. (2005). Indian economy (Vol. 888). Himalaya Publishing House.

32. Mugione, F. (2013, January). EMPRETEC inspiring entrepreneurship. In International Trade Forum (No. 1, p. 15). International Trade Centre.

33. Odularu, G. O. (2009). Export diversification as a promotion strategy for intra-ECOWAS trade expansion. African Journal of Business Management, 3(2), 32.

34. Ogunkola, E. O., \& Oyejide, T. A. (2001). Market access for Nigeria's exports in the European Union: An assessment of the 
impact of the Lome Convention and the Uruguay Round. The Nigerian Journal of Economic and Social Studies, 43(1), 15-45.

35. Onugu, B. A. N. (2005). Small and medium enterprises (SMEs) in Nigeria: Problems and prospects. St. Clements University, Nigeria (Unpublished Dissertation for a Doctor of Philosophy in Management Award).

36. Onwumere, J., \& Obasi, R. O. (2010). Analyses of Small-Scale Turkey Production in Owerri Agricultural Zone of Imo State, Nigeria. International Journal of Agriculture and Rural Development, 13(2).

37. Othman, M. K., Bolorunduro, P., Ibrahim, A., \& Dayot, B. (2009). Inventory Credit as Micro-Finance Tool for Community Development: A Pilot Study of Selected Farmers' Organizations in Two States of Northern Nigeria. Savanah Journal of Agriculture, 4, 30-39.

38. Oyejide, A., Ogunkola, A., \& Bankole, A. B. I. O. D. U. N. (2005). Import prohibition as a trade policy instrument: The Nigerian experience. Managing the Challenges of WTO Participation-45 Case Studies, 32.

39. Petrin, T. (1991). Is entrepreneurship possible in public enterprises?.

40. Prokopenko, J. (1994). The transition to a market economy and its implications for HRM in Eastern Europe. In Human Resource Management in Europe: Perspectives for the 1990s, 3rd Conference on international personnel and human resources management: Selected papers.(London: Routledge, 1994) (pp. 147-63).

41. Rose, A. K. (2007). The foreign service and foreign trade: embassies as export promotion. The World Economy, 30(1), 22-38.

42. Sanyang, S. E., \& Huang, W. C. (2010). Entrepreneurship and economic development: The EMPRETEC showcase. International Entrepreneurship and Management Journal, 6(3), 317-329.

43. Shariff, M. N. M., \& Saud, M. B. (2009). An attitude approach to the prediction of entrepreneurship on students at institution of higher learning in Malaysia. International Journal of Business and Management, 4(4), 129.

44. Singh, R., Verma, O. P., \& Anjum, B. (2012). Small scale industry: an engine of growth. Zenith International Journal of Business Economics \& Management Research, 2(5), 42-74.

45. Stefanović, I., Ranković, L., \& Prokić, S. (2011). Entrepreneurs' motivational factors: Empirical evidence from Serbia. Serbian Journal of Management, 6(1), 73-83. 
46. Tanzer, N. K. (2005). Developing tests for use in multiple languages and cultures: A plea for simultaneous development. Adapting educational and psychological tests for cross-cultural assessment, 235-263.

47. Timmons, J. A. (1989). The Entrepreneurial Mind. Brick House Publishing Co., ]

48. Titilayo, B. O., \& Victor, O. T. (2014). Bank consolidation and market structure in Nigeria: Application of the HerfindahlHirschman Index. International Journal of Economics and Finance, 6(2), 235.

49. Todd, P. R., \& Javalgi, R. R. G. (2007). Internationalization of SMEs in India: Fostering entrepreneurship by leveraging information technology. International journal of emerging markets, 2(2), 166-180.

50. UNDP, (2010). Small business financing: Federal Assistance and Contracts. New York, McGraw-Hill.

51. Urbano, D., \& Aparicio, S. (2016). Entrepreneurship capital types and economic growth: International evidence. Technological Forecasting and Social Change, 102, 34-44.

52. Van Praag, C. M., \& Cramer, J. S. (2001). The roots of entrepreneurship and labour demand: Individual ability and low risk aversion. Economica, 68(269), 45-62.

53. Vesper, K. H. (1983). Entrepreneurship and national policy (Vol. 3). Walter E. Heller International Corporation Institute for Small Business.

54. Zimmerman, M. A., \& Chu, H. M. (2013). Motivation, success, and problems of entrepreneurs in Venezuela. Journal of Management Policy and Practice, 14(2), 76. 